\title{
Audiodeskrypcja tradycyjna a audiodeskrypcja artystyczna: o wpływie języka i formy audiodeskrypcji na komfort jej odbioru przez osoby niewidome i niedowidzące
}

Audiodeskrypcja (AD) to technika narracyjna, umożliwiająca osobom niewidomym i niedowidzącym pełny dostęp do filmów, programów telewizyjnych, przedstawień teatralnych, wystaw w muzeach czy galeriach, a nawet widowisk sportowych. W przypadku produkcji filmowych i sztuk teatralnych dodatkowa ścieżka dźwiękowa pojawia się w przerwach pomiędzy dialogami. W ten sposób osobom niewidomym i niedowidzącym dostarczane są te informacje, które pozostali widzowie odbierają wyłącznie za pomocą wzroku, np. opisy miejsca akcji, pory dnia/roku, czynności wykonywanych przez bohaterów, ich strojów, mimiki, gestów ${ }^{1}$. W efekcie - przekładając obraz na słowo, a zatem znak niewerbalny na ciąg znaków werbalnych - audiodeskrypcja idealnie wpisuje się w definicję przekładu intersemiotycznego, wprowadzoną przez Romana Jakobsona, a następnie rozwiniętą przez innych naukowców, m.in. Jorgesa Diaz Cintas ${ }^{2}$ i Teresę Tomaszkiewicz [2008], która szczegółowo omawia rolę obrazu w komunikacji społecznej. Analogicznie, audiodeskryptorowi ${ }^{3}$ przyświeca taki sam cel, jak thumaczowi przekładającemu z języka wyjściowego A na język docelowy B, z tą różnicą, że w jego wypadku językiem wyjściowym jest obraz, docelowym natomiast ojczysty język odbiorcy audiodeskrypcji [por. Branje, Fels 2012, Chmiel, Mazur 2011].

${ }^{1}$ Definicja stworzona na podstawie http://www.audiodeskrypcja.org/articles.php?article_id=1 [dostęp 30.09.2013].

${ }_{2}$ Agnieszka Chmiel i Iwona Mazur powołują się na jego referat Accessibility and/in translation training wygłoszony w 2007 r. w Lublanie w czasie 5. Kongresu EST zatytułowanego Why Translation Studies matters.

${ }^{3}$ Nie ma oficjalnie przyjętej nazwy profesji osoby tworzącej audiodeskrypcję. Równolegle funkcjonują określenia audiodeskryptor, audiodeskryber oraz twórca audiodeskrypcji. 
Badania na temat audiodeskrypcji jako jednej z gałęzi przekładu audiowizualnego są $\mathrm{w}$ ostatnich latach prowadzone bardzo intensywnie nie tylko w ośrodkach uznawanych za pionierskie dla tej dziedziny, jak te w Stanach Zjednoczonych, Wielkiej Brytanii czy Hiszpanii, ale także w innych krajach, w tym w Polsce. Główny nacisk w badaniach tych kładzie się na poznanie preferencji osób niewidomych w kwestii stylu audiodeskrypcji, zwłaszcza zaś języka (rodzaju narracji, słownictwa, środków stylistycznych) i głosów wykorzystanych przy tworzeniu ścieżki audiodeskrypcji. Wyniki przeprowadzanych analiz mają stanowić podstawę do opisania jednolitych, jasnych zasad obowiązujących twórców audiodeskrypcji. Joel Snyder [2005] pośród czynników niezbędnych dla stworzenia dobrej audiodeskrypcji w pierwszej kolejności wymienia dobrze rozwinięty zmysł obserwacji audiodeskryptora, który ma rejestrować obraz i odmalowywać go za pomocą słów oraz umiejętność redakcji tekstu rozumianą jako wybór najważniejszych informacji, podyktowany koniecznością zawarcia w skrypcie audiodeskrypcji tego, co kluczowe dla zrozumienia filmu/sztuki, przy jednoczesnym skondensowaniu komunikatu tak, aby zmieścił się w przeznaczonym na niego czasie. Snyder podkreśla również znaczącą rolę języka audiodeskrypcji doboru właściwych słów, określeń trafnych, nacechowanych ${ }^{4}$ oraz użycia metafor i porównań przemawiających do wyobraźni odbiorców niewidomych czy niedowidzących. Jako ostatni element wpływający na jakość odbioru audiodeskrypcji, Snyder wymienia dobrą jakość nagrania/odczytania skryptu. Należy przy tym pamiętać, że istotne są nie tylko zdolności głosowe lektora czytającego narrację lub zastosowanie w audiodeskrypcji wysokiej jakości głosu syntetycznego jak najbardziej zbliżonego brzmieniem do głosu naturalnego, ale także odpowiednio dopasowana głośność ścieżki audiodeskrypcji.

Audiodeskryptor jest tłumaczem, i tak, jak od każdego tłumacza, oczekuje się od niego, że będzie prawie niewidzialny. Audiodeskrypcja - analogicznie - powinna być jak najbardziej obiektywna, aby zagwarantować odbiorcy możliwość w pełni samodzielnej interpretacji „oglądanego” programu/filmu/przedstawienia itp. Jako thumacza audiowizualnego, audiodeskryptora ogranicza jednak nie tylko czynnik językowy, ale także czynniki pozajęzykowe związane z konstrukcją filmu: ilością dialogów (i momentów ciszy) czy natężeniem akcji. Dobra audiodeskrypcja musi być zatem zwartym opisem, musi też nadążać za filmem, ale go nie wyprzedzać, ponieważ nie może zdradzać niewidomemu odbiorcy informacji, które pozostali widzowie otrzymają dopiero później. Te wszystkie czynniki sprawiają, że stworzenie skryptu audiodeskrypcji w stu procentach spełniającego swoją najbardziej podstawową funkcję (informacyjną), a przy tym jeszcze - co wynika z natury audiodeskrypcji artystycznej - atrakcyjnego, być może nietypo-

${ }^{4}$ Np. zamiast idzie można powiedzieć kroczy, spaceruje, przechadza się, maszeruje, przekazując w ten sposób bardziej kompleksową informację na temat tego, co się dzieje na ekranie. 
wego pod względem języka, formy czy sposobu realizacji, stanowiącego część rozrywki, jest sporym wyzwaniem dla jej autora.

15 kwietnia 2013 r. w Specjalnym Ośrodku Szkolno-Wychowawczym w Krakowie przeprowadziłam badanie na temat audiodeskrypcji artystycznej $j^{5}$. Jedna z jego części dotyczyła wpływu języka i formy audiodeskrypcji na komfort jej odbioru przez osoby niewidome i niedowidzące. W badaniu tym wzięły udział dzieci ${ }^{6}$ i młodzież - wychowankowie ośrodka. W kolejnych dniach ankiety zostały wypełnione także przez dorosłych niewidomych i niedowidzących, do których udało się dotrzeć drogą mailową. Badanie miało zweryfikować, w jakim stopniu wybór formy audiodeskrypcji, słownictwa oraz środków stylistycznych wpływa na sposób oraz poprawność interpretacji „obejrzanego” filmu. Miało ono również pomóc ustalić, która forma audiodeskrypcji - artystyczna czy tradycyjna - bardziej przemawia do wyobraźni, a co za tym idzie, która jest bardziej komfortowa w odbiorze, czy osoby niewidome uznają AD artystyczną za atrakcyjniejszą, czy wręcz przeciwnie, opowiedzą się po stronie AD tradycyjnej. Tym samym badanie miało dać odpowiedź na pytanie, czy AD artystyczna, której forma niejednokrotnie determinuje wybory audiodeskryptora $\mathrm{w}$ realizowanym przez niego procesie thumaczenia, ma szansę zastąpić obraz, czy nie ulegnie on zbytniemu zniekształceniu, uniemożliwiając zrozumienie filmu.

W badaniu wzięło udział dwadzieścioro jeden dzieci, z czego dziesięcioro niewidzących (ośmioro z nich nie widzi od urodzenia, dwoje pozostałych straciło wzrok w wieku przedszkolnym i wczesnoszkolnym), jedenaścioro niedowidzących oraz dziewiętnaście osób dorosłych - jedenaście niewidomych (z tego osiem od urodzenia) i osiem niedowidzących lub słabowidzących. W badaniu wykorzystana została polska wersja językowa krótkometrażowego filmu animowanego „Odbijany” nagranego w 2003 r. przez wytwórnię PIXAR. Na potrzeby badania do filmu zostały przygotowane dwie ścieżki audiodeskrypcji - artystyczna (w tym wypadku rymowana) i tradycyjna, obie powstały w oparciu o konsultacje z osobą niewidomą. Tradycyjną wersję audiodeskrypcji nagrano przy użyciu syntetycznego głosu męskiego JACEK z pakietu głosów Ivona Reader, skrypt rymowany został przeczytany przez lektora. Uczestnicy badania oglądali film dwukrotnie, najpierw wersję z AD artystyczną, następnie z AD tradycyjną. Po każdej projekcji odpowiadali na pytania dotyczące zarówno treści bajki (dzieci), jak i kwestii technicznych związanych z zaproponowaną audiodeskrypcją.

${ }^{5}$ Było to pierwsze $\mathrm{z}$ zaplanowanej serii badań na temat audiodeskrypcji artystycznej. W dalszych badaniach na tym i kolejnym materiale audiowizualnym planuję przeanalizować odpowiedzi dzieci i młodzieży z innych polskich placówek szkolno-wychowawczych dla osób z dysfunkcją wzroku.

${ }^{6} \mathrm{~W}$ badaniu wzięły udział dzieci w wieku 6-13 lat (strukturę ich wieku przedstawia rys. 3). Najstarsza osoba dorosła biorąca udział w badaniu miała 30 lat. 
DZIECI

- niewidome (10) || niedowidzące (11)

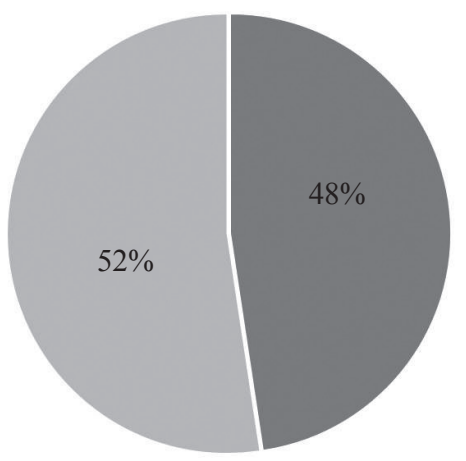

Rys. 1. Uczestnicy badania: dzieci

MŁODZIEŻ I DOROŚLI

- niewidomi (11) niedowidzący (8)

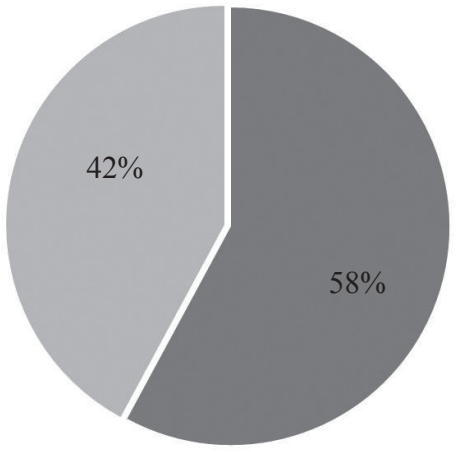

Rys. 2. Uczestnicy badania: młodzież i dorośli

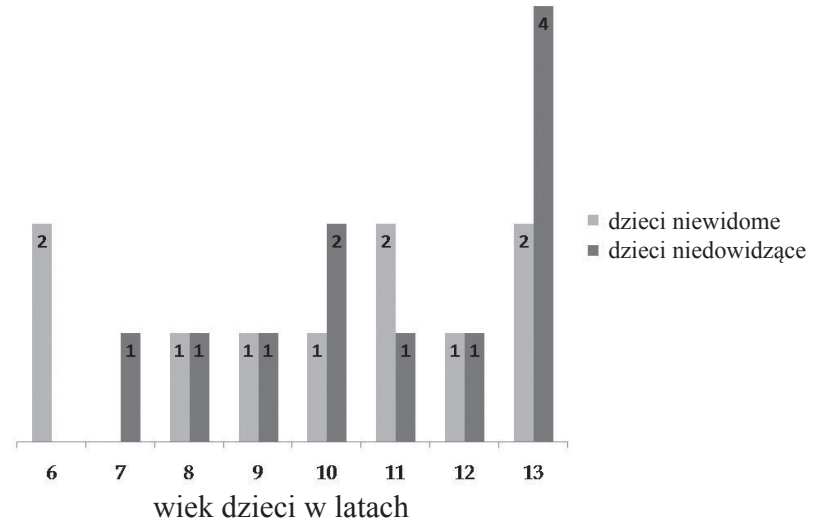

Rys. 3. Dzieci biorące udział w badaniu - podział ze względu na wiek 
Obie wersje bajki zostały bardzo pozytywnie przyjęte przez niewidomych widzów. Dzieci uznały, że była ona interesująca i zabawna. Wielokrotnie podkreślały to, że bardzo lubią oglądać filmy animowane i programy dla dzieci, a nieczęsto mają możliwość robić to samodzielnie. W Polsce jak dotąd jest bardzo niewiele opatrzonych audiodeskrypcją programów i filmów dla najmłodszych, stąd zazwyczaj rodzice lub widzące rodzeństwo muszą towarzyszyć dzieciom niewidomym podczas oglądania telewizji i opowiadać, co się dzieje na ekranie. Jako bajka z morałem oraz pełna humoru i żartów słownych, „Odbijany" bardzo przypadł do gustu również starszej widowni, a ponieważ jest bajką w całości rymowaną, audiodeskrypcję artystyczną postanowiono utrzymać w podobnym tonie.

W pierwszej kolejności dzieci zostały zapytane o to, z którą wersją audiodeskrypcji film był dla nich łatwiejszy do zrozumienia.

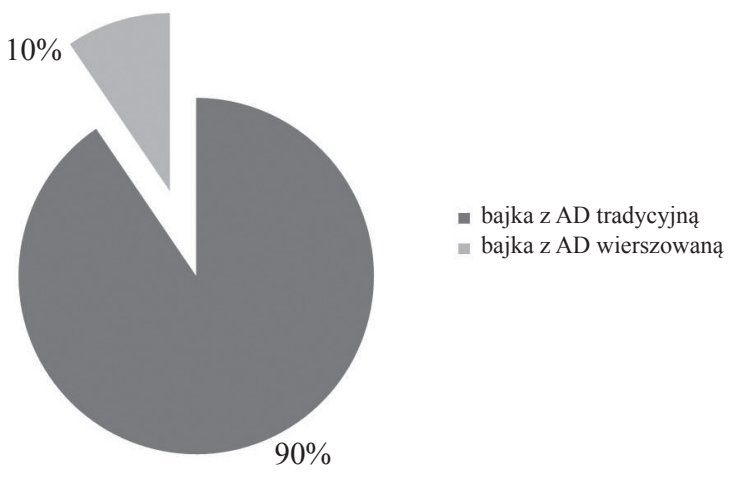

Rys. 4. Ocena trudności ścieżek audiodeskrypcji przez dzieci niewidome i niedowidzące

Tylko dwoje dzieci (i to niedowidzących, w wieku 11-12 lat) uznało AD wierszowaną za przyjemniejszą i w związku z tym za łatwiejszą w odbiorze. Pozostałe dzieci, nawet te, którym bardziej podobała się audiodeskrypcja artystyczna (por. rys. 4), uznały, że ta tradycyjna lepiej spełnia swoje zadanie, bo jest dla nich bardziej zrozumiała, nie wymaga wielkiego skupienia $\mathrm{i}$ intensywnego myślenia nad tym, co się usłyszało. Dzieci dzieliły się też na te, którym podobało się, że AD wierszowana wtapia się w bajkę i wraz z kwestiami wypowiadanymi przez postacie stanowi spójną całość, oraz na te, dla których było to dodatkowym utrudnieniem, bo wolą, gdy audiodeskrypcja jest zupełnie oddzielnym, neutralnym opisem, natomiast brak wyraźnego podziału pomiędzy dialogami a tekstem wprowadzanym przez audiodeskrypcję jest dla nich dezorientujący. 


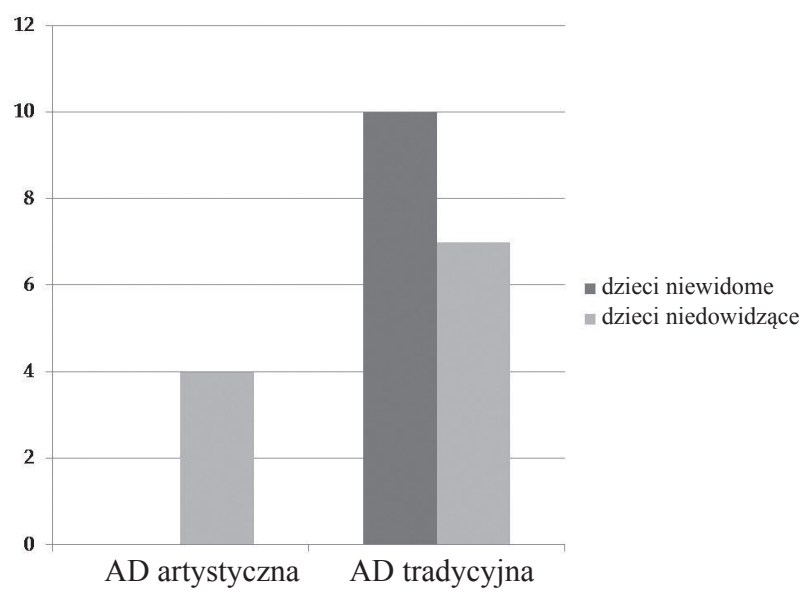

Rys. 5. Ocena atrakcyjności ścieżek audiodeskrypcji przez dzieci niewidome i niedowidzące

Dla dzieci, zwłaszcza młodszych, pytanie o to, z którą wersją audiodeskrypcji bajka podobała im się bardziej, jest zazwyczaj tożsame z pytaniem o to, w której wersji jest ona dla nich bardziej zrozumiała. Dzieciom nie podoba się to, czego nie rozumieją, łatwo je zniechęcić, stawiając im poprzeczkę zbyt wysoko. Starsze dzieci, mając lepiej rozwinięte kompetencje językowe (i to najczęściej dzieci niedowidzące, a nie niewidome), deklarowały, że rymy są dla nich dodatkowo zabawne, że są czynnikiem podnoszącym atrakcyjność bajki. Jednak dla większości (17) respondentów w wieku szkolnym to AD tradycyjna okazała się być zabawniejsza. Dzieje się tak właśnie dlatego, że jest ona dla nich bardziej przystępna (są w stanie wychwycić więcej niuansów czy żartów sytuacyjnych), wymaga od nich mniej skupienia, mniej wysiłku, stanowiąc przez to czystą rozrywkę. Dzieci mówiły o tym, że przestawiony szyk zdania w AD rymowanej lub wyrazy, których w danym miejscu nie spodziewały się usłyszeć, sprawiały, że czasami nie od razu było dla nich jasne, co tak naprawdę dzieje się na ekranie i musiały się mocniej skupiać na znaczeniu usłyszanego tekstu. Co ciekawe, jak wykazało badanie, już 8-9-latki zwracają uwagę na głos czytający audiodeskrypcję jako na czynnik wpływający na komfort jej odbioru. Praktycznie wszystkie dzieci zadeklarowały, że w AD artystycznej bardzo podobał im się przyjemny, naturalny głos. Jeden chłopiec (11 lat) zwrócił też uwagę na głos syntetyczny wykorzystany do nagrania skryptu AD tradycyjnej. Potrafił on zidentyfikować ten głos, ponieważ często go używa i - jak mówił - bardzo go lubi. Opinia tego chłopca dowodzi, że warto już od najmłodszych lat zaznajamiać dzieci z audiodeskrypcją czytaną przez głosy syntetyczne, gdyż w ten sposób dzieci się z nimi oswajają, co pozytywnie wpływa na ich komfort odbioru takiej właśnie audiodeskrypcji. Obcowanie od najmłodszych lat z różnymi technikami audiodeskrypcyjnymi sprawi, że dzieci staną 
się bardziej obyte $\mathrm{w}$ tej materii, sprawniejsze jako widzowie, a w przyszłości z większą swobodą będą korzystały i z nietypowej audiodeskrypcji artystycznej, $\mathrm{i}$ - przede wszystkim - z audiodeskrypcji czytanej przez syntezatory mowy. To z kolei rozszerzy ich możliwości dostępu do kina, teatru, wystaw czy choćby programów telewizyjnych, gdyż AD czytana przez syntezator mowy jest dużo tańsza w produkcji aniżeli ta nagrywana przez lektora, przez co może być powszechniej stosowana. Mimo że mowa syntetyczna jest obecnie coraz bardziej wyraźna i poprawna, to wciąż jeszcze brak jej ekspresji typowej dla głosu ludzkiego, przez co potrzebny jest jakiś czas na osłuchanie się i oswojenie z nią [por. Walter 2007: 103-104]. Wyniki badań przeprowadzonych w latach 2010-2011 przez Annę Jankowską i Agnieszkę Szarkowską potwierdzają, że audiodeskrypcja czytana przez syntezator mowy jest zdecydowanie lepiej odbierana przez osoby przyzwyczajone do sztucznych głosów. Co zaskakujące, wśród badanych były zarówno osoby, które nie akceptowały audiodeskrypcji syntetycznej nawet jako narzędzia tymczasowego, jak i jedna osoba preferująca głos sztuczny, nie naturalny [por. Szarkowska 2011]. To powinno stanowić bodziec do wytężonej aktywności równolegle w dwóch kierunkach: $\mathrm{z}$ jednej strony należałoby się skupić na polepszaniu jakości sztucznej mowy, z drugiej - na propagowaniu audiodeskrypcji i wiedzy na jej temat oraz audiodeskrybowaniu filmów i programów (ze szczególnym uwzględnieniem tych przeznaczonych dla dzieci) w ramach pewnego standardu, takiego, jakim jest np. wybór opcji językowej na płytach DVD.

Powyższe uwagi na temat wpływu doświadczenia widza na jego komfort odbioru $\mathrm{AD}$ znajdują potwierdzenie w wynikach ankiety przeprowadzonej wśród dorosłych niewidomych i niedowidzących.

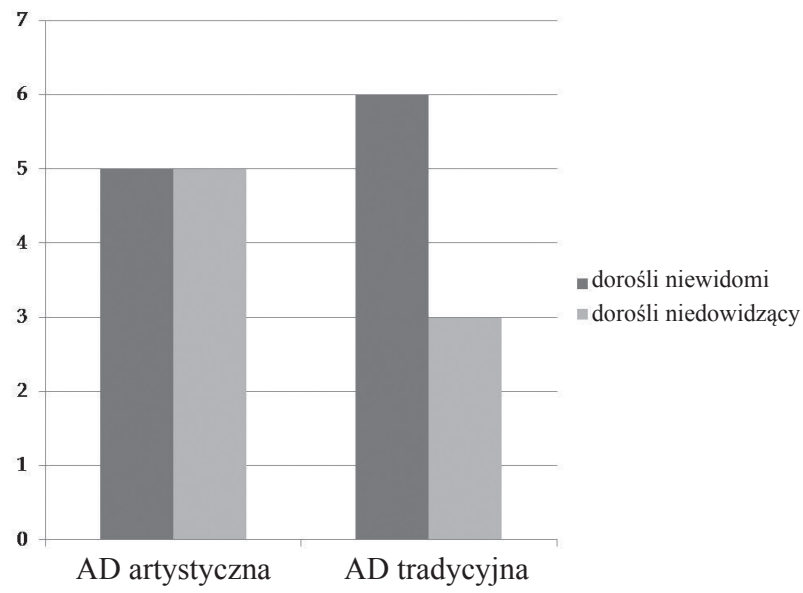

Rys. 6. Ocena atrakcyjności ścieżek audiodeskrypcji przez osoby dorosłe niewidome i niedowidzące 
Jako lepszą AD artystyczną sklasyfikowało pięć osób niewidomych i pięć niedowidzących, za AD tradycyjną natomiast opowiedziało się sześć osób niewidomych i trzy niedowidzące. Swoje preferencje dorośli niewidomi argumentowali w podobny sposób jak dzieci. Uznali oni, że AD artystyczna wymaga większej koncentracji, a wszelkie udziwnienia składni i słownictwa oraz zniekształcenia głosów mogą rozpraszać mniej doświadczonego widza, ponieważ musi się on skupiać na rozumieniu audiodeskrypcji, zamiast na treści bajki. Celem audiodeskrypcji jest szybkie przekazanie obrazu, a nie wszystko da się szybko wychwycić przy AD wierszowanej, gdyż jest ona bardziej skomplikowana. Według opinii dorosłych respondentów w kilkuminutowej bajce AD wierszowana była jak najbardziej do przyjęcia, ale zaznaczali oni, że w przypadku dłuższego filmu mogłaby się nie sprawdzić. $Z$ tego powodu, jak również dlatego, że AD wierszowaną oceniali jako bardziej stymulującą językowo, chętniej widzieli ją w programach dla dzieci, w tym w bajkach niemych. Także biorąc pod uwagę kryterium obiektywności, dorośli ankietowani wyżej ocenili AD tradycyjną. Ich zdaniem forma wypowiedzi przy AD artystycznej oraz modulacja głosu lektora bardzo silnie narzucają interpretację treści bajki, chociaż to właśnie rymy sprawiły, że w wielu miejscach taka audiodeskrypcja była bardziej atrakcyjna niż ta tradycyjna. W opinii znacznej większości osób niedowidzących i słabowidzących AD artystyczna była bardzo śmieszna, pasowała do tego filmu, który miał komediowy charakter, bo przez rymy sprawiała, że był dodatkowo zabawny i humorystyczny. Jednocześnie, podobnie jak niewidomi, osoby te zwracały uwage na fakt, że przez swoją nietypową formę i wybory leksykalne podyktowane koniecznością utrzymania stylu, może być trudniejsza w odbiorze. Należy tu koniecznie zwrócić uwagę na fakt, że ocena atrakcyjności AD rymowanej była na ogół zależna od stopnia uszkodzenia wzroku ankietowanych osób: niedowidzący i słabowidzący oceniali ją wyżej ${ }^{7}$. Dzieje się tak dlatego, że osoby te w sposób automatyczny posługują się wzrokiem, a audiodeskrypcja stanowi dla nich jedynie dodatkowe wsparcie.

Wyniki przeprowadzonego badania jednoznacznie pokazują, że dla osób niewidomych (również tych najmłodszych) w audiodeskrypcji najważniejsza jest jasność przekazu. Co się tyczy upodobań w zakresie stylu audiodeskrypcji, możemy stwierdzić, że w znacznym stopniu zależą one od gustu samych zainteresowanych. Audiodeskryptor, odpowiednio dobierając formę do programu, filmu czy sztuki teatralnej, może je wzbogacić pod względem estetycznym i poniekąd zrekompensować niewidomym brak bodźców wizualnych. Zawsze jednak musi pamiętać o tym, że osobom korzystającym z audiodeskrypcji zależy przede wszystkim na jej funkcji informacyjnej oraz na obiektywności opisu. Należy też odpowiednio dobrać poziom trudności każdej audiodeskrypcji do wieku, wiedzy i umiejętności widowni docelowej.

${ }^{7}$ Dotyczy to szesnastu na dziewiętnaście osób, co stanowi 84\% grupy ankietowanych. 
Choć wszyscy badani podkreślają wartość naturalnego brzmienia głosu, to wśród nich są osoby, które między innymi z tego powodu preferują głos syntezatora, że nie zdradza on emocji, nie dodaje treści [por. Zabrocka, w druku]. Maksymalna możliwa obiektywność audiodeskrypcji jest niezbędna, aby niewidomym odbiorcom nie narzucać naszego sposobu widzenia rzeczywistości, ale za pomocą słów oddać jak najwierniej świat przedstawiony, tym samym dając im szansę budowania ich własnej wizji tego świata.

Osoby niedowidzące i te, które straciły wzrok w wieku szkolnym i późniejszym (szczególnie zaś dzieci) mówiły, że ich zdaniem w obu zaproponowanych w badaniu audiodeskrypcjach przydałoby się więcej informacji na temat miejsca życia owieczki, przyrody, wyglądu zwierząt, a nawet kolorów. Również głównie w przypadku dzieci ważne jest tempo narracji, które musi być dostosowane do trudności języka audiodeskrypcji.

Dla ankietowanych tło dźwiękowe bajki było równie ważnym co sama audiodeskrypcja nośnikiem informacji na temat akcji oraz źródłem przeżyć estetycznych. Audiodeskrypcja powinna być na tyle głośna, aby nie trzeba było się nadmiernie skupiać, by ją usłyszeć, ale też nie powinna zagłuszać odgłosów tła. Niewidomi podkreślali, że chociaż zależy im na maksymalnej ilości detali, to dobra AD nie może być przeładowana tekstem, gdyż momenty ciszy są równie ważne. Powyższe uwagi prowadzą do wniosków, że audiodeskrypcja nie może się narzucać odbiorcy. Jedna z ankietowanych osób napisała, że ,audiodeskrypcja powinna być spokojnym towarzyszem". Zatem dobra audiodeskrypcja to taka, której się przyjemnie słucha, i którą się bez trudu przyswaja, ponieważ z założenia ma ona być dla osoby niewidomej tak automatyczna w odbiorze, jak obraz dla osoby widzącej [por. Mälzer-Semlinger 2012: 30].

W ogólnej ocenie zdecydowanie lepiej wypadła AD tradycyjna - spokojniejsza i bardziej neutralna - co jednak (również zdaniem samym badanych) nie powinno przesądzać o losie AD artystycznej, która ich zdaniem dobrze sprawdzi się przede wszystkim w programach i filmach dla najmłodszych widzów, tym bardziej, że - odpowiednio przygotowana - może stanowić wspaniałe narzędzie wspomagające językowy rozwój dziecka. Również na korzyść AD tradycyjnej przemawia fakt, że istnieje możliwość jej stosunkowo prostego przekładu z języków obcych, co znacznie przyspiesza proces jej tworzenia. Z kolei dzięki temu, że AD tradycyjna nie musi być nagrywana przez lektora, obniża się koszt jej produkcji. Osoby niewidome mają świadomość tego, że AD z syntezą mowy jest tańsza, co w większości wypadków z góry pozytywnie ich do niej nastawia, gdyż upatrują w niej szansy na szybszy dostęp do większej ilości najnowszych produkcji audiowizualnych.

W przypadku opisanego tu badania, dość bogata $\mathrm{AD}$ rymowana u bardziej wyrobionych widzów nie zniekształciła w sposób znaczący obrazu świata przedstawionego w filmie „Odbijany”. Jednak mniej doświadczonej widowni, czyli de facto młodszym dzieciom, słabiej rozwiniętym pod względem językowym, 
pewne szczegóły umknęły lub nie zostały przez nie do końca zrozumiane, co w efekcie mogło prowadzić do tego, że ich wizja świata była uboższa aniżeli ta, którą pozwoliła im stworzyć AD tradycyjna.

\section{Bibliografia}

Branje C. J., Fels D. I. [2012], LiveDescribe: Can Amateur Describers Create High-Quality Audio Description?, „Journal of Visual Impairment \& Blindness”, march 2012.

Chmiel A., Mazur I. [2011], Audiodeskrypcja jako intersemiotyczny przektad audiowizualny - percepcja produktu i ocena jakości, [w:] I. Kasperska, A. Żuchelkowska (red.), Przekład jako produkt i kontekst jego odbioru, Wydawnictwo Rys, Poznań.

Mälzer-Semlinger N. [2012], Narration or description: What should audio description „look” like?, [w:] E. Perego (red.), Emerging topics in translation: Audio description, EUT Edizioni Università di Trieste, s. 29-36.

Snyder J. [2005], Audio Description: The visual made verbal, http://www.audiodescribe.com/links/ AD-The\%20Visual\%20Made\%20Verbal.pdf [dostęp 30.09.2013].

Szarkowska A. [2011], Audiodeskrypcja z synteza mowy, http://avt.ils.uw.edu.pl/ad-tts/ [dostęp 30.09.2013].

Tomaszkiewicz T. [2008], Przekład audiowizualny, Wydawnictwo Naukowe PWN, Warszawa.

Walter N. [2007], Nowe media dla niewidomych i słabowidzacych, Wydawnictwo Naukowe UAM, Poznań.

Zabrocka M. [w druku], Audiodeskrypcja artystyczna w odbiorze osób niewidomych i niedowidzqcych. 